A N N A L ES

UNIVERSITATIS MARIAE CURIE-SKŁODOWSKA

LUBLIN - POLONIA

VOL. LXII, 2

SECTIO G

2015

MARIA BOSAK

\title{
Zjawisko krytyki w stosunkach pracy - wybrane aspekty
}

The Phenomenon of Criticism in Labour Relations - Selected Aspects

Rozważania na temat krytyki w środowisku pracy wiążą się z podstawowym celem przypisanym pracowniczemu zatrudnieniu, zasadniczo sprowadzającym się do racjonalności instrumentalnej i komunikacyjnej ${ }^{1}$. Ma ono bowiem charakter zobowiązaniowy i ciągły, zaś jego wykonywanie odbywa się pod kierownictwem pracodawcy, a więc już z istoty wynika potrzeba angażowania osoby pracownika w proces wykonywania pracy w sposób określony ${ }^{2}$, także przez wydawanie poleceń, a nie jedynie skupianie się na efektach końcowych prowadzonej działalności. Ponadto stosunek pracy jako więź prawna łącząca pracownika i pracodawcę oprócz ustalonych pierwotnych założeń towarzyszących jego prawidłowej realizacji ma również na celu wypełnienie funkcji polegającej na wzajemnej ochronie tworzących go podmiotów ${ }^{3}$. Ochrona w tym przypadku będzie polegać nie tylko na eliminowaniu czy ograniczaniu szkodliwych czynników o charakterze zewnętrznym, ale powinna przekładać się też na relacje wewnętrzne kształtowane przez same strony stosunku pracy. Znaczna część tych ostatnich wynika m.in. z treści szeroko pojętych powszechnych i autonomicznych źródeł prawa pracy oraz z zasad współżycia społecznego i dobrych obyczajów, chociaż oczywistym jest, że i one nie wskazują wszystkich okoliczności mogących naruszać zasady towarzyszące prawidłowemu istnieniu stosunku pracy. Już z treści art. 1 wynika, że kodeks pracy określa prawa i obowiązki zarówno pracowników, jak i pracodawców.

1 L. Morawski, Główne problemy współczesnej filozofii prawa. Prawo w toku przemian, Warszawa 2005, s. 155-158.

2 Szerzej: wyrok Sądu Najwyższego z dnia 19 marca 2014 roku, I PK 187/13, Lex nr 1475152.

3 Szerzej na ten temat: M. Bosak, D. Habrat, Granice krytyki w stosunkach pracy, [w:] 40 lat Kodeksu pracy, pod red. Z. Górala, M.A. Mielczarka, Warszawa 2015, s. 334-345. 
Niniejsza analiza będzie ograniczać się do jednego z aspektów składających się zarówno na prawo, jak i obowiązek obciążający oba podmioty stosunku pracy, a także konsekwencji związanych z zaniechaniem jego przestrzegania. Zostanie ona jednak zawężona do regulacji wynikających z kodeksu pracy.

Za prawo w tym przypadku należy uznać dbałość o środowisko pracy wolne od nieuzasadnionej krytyki, mającej postać jednostronną lub dwustronną, mieszczącą się w granicach konkretnego stosunku pracy, ale w pewnych okolicznościach, o czym będzie mowa w dalszej części, wykraczającą poza jego zakres, w każdym jednak przypadku powodującą szkodę, zaś obowiązkiem spoczywającym na stronach stosunku pracy będzie nakaz jego przestrzegania. Najpoważniejszą konsekwencją jego przekroczenia może być natomiast rozwiązanie stosunku pracy lub kolejno odwołanie się do innych dostępnych środków prawnych mających służyć dyscyplinowaniu pracownika.

Nie ulega wątpliwości, że jednym z czynników mogących potencjalnie zaburzyć prawidłowe relacje w stosunkach pracy jest właśnie zjawisko krytyki. Ustawodawca pracy nie definiuje samodzielnie tego pojęcia ani nawet go nie wymienia, dlatego na wstępie należy odwołać się do potocznego rozumienia wskazanego terminu. Za krytykę zatem, zgodnie ze Stownikiem języka polskiego, uznaje się analizę wartości czegoś, ocenę ujemną, ganienie, wytykanie błędów ${ }^{4}$. Zgodnie z powyższym krytyka, co do zasady, kojarzy się z postępowaniem obiektywnie pejoratywnym, niepożądanym, krzywdzącym i szkodliwym dla adresata. Dopiero wystąpienie wskazanych cech kwalifikuje ją jako nieuzasadnioną, w odróżnieniu od krytyki uzasadnionej, zwanej także dopuszczalną, mającą również oparcie w obiektywnych, rzeczywistych i racjonalnych argumentach. Truizmem byłoby założenie, iż w środowisku pracy, ale i w każdym innym, gdzie występuje cecha podporządkowania, możliwe byłoby całkowite wyeliminowanie tego zjawiska i uznanie go za działanie niecelowe. Taki stan rzeczy przeczyłby bowiem istocie podporządkowanego zatrudnienia stanowiącego jednak jedną z jego immanentnych cech.

Co do zasady przez krytykę wyraża się dezaprobatę, więc stanowi ona naturalną reakcję na zespół zachowań w pierwszej kolejności sprzecznych z katalogiem podstawowych praw i obowiązków przysługujących w analizowanym przypadku z tytułu istniejącego stosunku pracy. Prawo do dozwolonej krytyki należy uznać także jako element wolności wyrażania swoich poglądów zawarty zarówno w art. 54 ust. 1 obowiązującej Konstytucji, jak i w aktach o randze międzynarodowej (w tym art. 10 Konwencji Europejskiej) ${ }^{5}$. Wskazana problematyka mieści się ponadto w katalogu podstawowych zasad prawa pracy, gdzie ustawodawca $\mathrm{w}$ art. $11^{1} \mathrm{k}$.p. wymienia m.in. obowiązek polegający na poszanowaniu godności

4 Mały słownik języka polskiego, pod red. E. Sobol, Warszawa 2004, s. 362.

5 Szerzej: S. Ciupa, Niedozwolona krytyka pracodawcy ze strony pracownika jako przyczyna wypowiedzenia umowy o prace, „Monitor Pracy” 2002, nr 20, s. 925. 
i innych dóbr osobistych pracownika, do którego zobowiązuje on akurat w tym miejscu bezpośrednio pracodawcę. Zaznaczenia wymaga, że wspomniany przepis nie daje podstawy do uznania godności pracowniczej za kategorię odrębną i niemającą związku z najszerszym ujęciem ochrony dóbr osobistych przynależnych każdemu człowiekowi ${ }^{6}$, przy czym w literaturze tradycyjnie odróżnia się pojęcie godności osobowej ${ }^{7}$ od godności osobowościowej ${ }^{8}$. Zgodnie z powyższym godność osobowa z założenia jest przynależna każdemu człowiekowi, godność osobowościowa zaś odnosi się do konkretnego człowieka i jego osobistego poczucia wartości wywodzącego się z życiowych zasług9. W tym miejscu należy wskazać, iż w omawianym aspekcie równie istotne będzie podkreślenie godności osobowościowej przysługującej nie tylko pracownikowi, ale i pracodawcy będącemu osobą fizyczną. Jak podkreśla Sąd Najwyższy, w razie analizowanych wątpliwości chodzi tutaj bowiem o obowiązki pracownika wobec pracodawcy, a nie wobec osób fizycznych go reprezentujących ${ }^{10}$. Wobec powyższego pracownik nie jest uprawniony do bezkarnego przekazywania gołosłownych zarzutów i umyślnego dążenia prowadzącego do zniesławienia pracodawcy ${ }^{11}$. Podobnie troska o interesy pracodawcy nie może usprawiedliwić jego nagannego postępowania polegającego na obrażaniu kierownika przez przypisywanie mu cech poniżających go w opinii publicznej ${ }^{12}$ czy też na przypisywaniu członkowi organu pracodawcy, będącego osobą prawną, bezpodstawnego zarzutu popełnienia przestępstwa ${ }^{13}$.

Przedmiot rozważań podjętych $\mathrm{w}$ omawianym aspekcie będzie odnosił się do godności osobowościowej przysługującej z tytułu istniejącego stosunku pracy ${ }^{14}$, które wchodzą w skład szeroko pojętych interesów pracownika i zatrudniającego go pracodawcy. Na interesy te, co zostało podkreślone przez doktrynę przedmiotu, składa się szereg okoliczności i celów integralnie związanych z podmiotami stosunku pracy, ich życiem osobistym, dla których praca stanowi środek służący

6 Szerzej: wyrok Sądu Najwyższego z dnia 2 lutego 2011 roku, II PK 189/10, MoPr 2011, nr 8, s. 394.

7 Szerzej na temat pojęcia godności: M. Kryszkiewicz, Godność w prawie pracy, [w:] Wartości i interesy a prawo pracy, pod red. M. Włodarczyka, Łódź 2014, s. 44-48.

8 F.J. Mazurek, Godność osoby ludzkiej podstawa praw człowieka, Lublin 2001, s. 17-19.

9 Szerzej: A. Sobczyk, Prawo pracy w świetle Konstytucji RP, t. 1, Warszawa 2013, s. 118 -121.

10 Tak: Sąd Najwyższy w uzasadnieniu do wyroku z dnia 28 sierpnia 2013 roku, I PK 48/13, Legalis nr 830616.

11 Szerzej: Sąd Najwyższy w wyroku z dnia 11 kwietnia 1984 roku, I PR 34/84, OSPiKA 1985, nr 9, poz. 161.

12 Tak: Sąd Najwyższy w wyroku z dnia 13 października 1999 roku, I PKN 296/99, OSNAPiUS 2001, nr 4, poz. 114.

13 Szerzej: wyrok Sądu Najwyższego z dnia 7 marca 1997 roku, I PKN 28/97, OSNAPiUS 1997, nr 24, poz. 487; wyrok Sądu Najwyższego z dnia 12 stycznia 2005 roku, I PK 145/04, OSNP 2005, nr 16, poz. 243.

14 Szerzej na ten temat: H. Szewczyk, Ochrona dóbr osobistych w zatrudnieniu, Warszawa 2007, s. 27. 
właściwej realizacji, zaś interes ten pozostaje chroniony na poziomie społecznie akceptowalnym ${ }^{15}$.

W dalszej części przepisów kodeksu pracy, wśród otwartego katalogu zawierającego podstawowe obowiązki pracownika wskazano, że zobowiązuje się go w szczególności m.in. do dbałości o dobro zakładu pracy oraz przestrzegania zasad współżycia społecznego. Ze względu na ogólne brzmienie cytowanych sformułowań wydaje się, że zasadne będzie uznanie ich za nawiązanie do wymienionej wcześniej podstawowej zasady, która w tym konkretnym przypadku została skierowana do pracownika. Zaznaczenia wymaga, że wskazane nakazy będą obowiązywać pracownika zarówno wobec pracodawcy, jak i pozostałych współpracowników. W literaturze przedmiotu słusznie zwrócono uwagę, że obowiązek ten, oprócz ogólnych zasad wynikających ze zobowiązaniowego charakteru stosunku pracy, ma także inny równie ważny cel, a mianowicie jego wypełnienie $\mathrm{w}$ dużej mierze decyduje o prawidłowości przebiegu pracy zespołowej, a więc w konsekwencji staje się on obowiązkiem o charakterze powszechnym, nie zaś prywatnym ${ }^{16}$. Nie można pominąć, że na szeroko pojętą dbałość o dobro zakładu pracy ma wpływ również odpowiednia postawa pracownika, $\mathrm{w}$ tym konkretnym przypadku wyrażająca się w lojalności należnej zatrudniającemu go pracodawcy oraz współpracownikom. Przeciwieństwem właściwej i odpowiedniej postawy pracownika w stosunku do pracodawcy będzie, na co zwraca uwage w jednym z wyroków Sąd Najwyższy, wywieszanie na tablicy ogłoszeń obraźliwych tekstów skierowanych wobec pełnomocnika pracodawcy, polegających na negowaniu jego kompetencji czy zarzucaniu mu popełnienia nadużyć w zakresie pobierania zaliczek i wywożenia za granicę pieniędzy z pominięciem systemu bankowego ${ }^{17}$, a także lekceważące i aroganckie wypowiedzi w stosunku do pełnomocnika wyznaczonego przez pracodawcę ${ }^{18}$.

Powyższa okoliczność jednak nie może oznaczać, że krytyka w każdym przypadku będzie stanowić ryzyko rozwiązania stosunku pracy bądź próby zakwalifikowania określonych zdarzeń $\mathrm{w}$ konwencji prawnych kategorii mobbingu ${ }^{19}$. Jako

15 Szerzej: M. Włodarczyk, Wartości i interesy a prawo pracy-tytułem wstępu, [w:] Wartości $i$ interesy..., s. 10.

16 Szerzej na ten temat: D. Dörre-Kolasa, Komentarz do art. 100, [w:] Kodeks pracy. Komentarz, pod red. A. Sobczyk, Warszawa 2014, s. 464-465.

17 Tak: Sąd Najwyższy w wyroku z dnia 1 października 1997 roku, I PKN237/97, OSNAPiUS 1998, nr 14, poz. 420.

18 Tak: Sad Najwyższy w wyroku z dnia 11 czerwca 1997 roku, I PKN 202/97, OSNAPiUS 1998, nr 10, poz. 297.

19 Zob. wyrok Sądu Apelacyjnego w Katowicach z dnia 15 grudnia 2006 roku, III APa 170/05, OSA/Kat, 2007, nr 3, poz. 4; Wieloaspektowość mobbingu w stosunkach pracy, pod red. T. Wyki, C. Szmidta, Warszawa 2012; M. Bosak, A. Danilewicz, Odpowiedzialność cywilna i karna za mobbing, „Prokuratura i Prawo” 2010, nr 4, s. 103-113; H. Szewczyk, Mobbing w stosunkach pracy, Warszawa 2012, s. 111-148 (rozdział IV). 
potwierdzenie powyższej tezy warto przytoczyć jedno z najnowszych orzeczeń Sądu Najwyższego, zgodnie z którym dozwolona i konstruktywna krytyka nie tylko nie narusza, ale wręcz może świadczyć o dbałości o dobro zakładu pracy ${ }^{20}$, którego - co wymaga podkreślenia - nie można w każdym przypadku utożsamiać z dobrem pracodawcy ${ }^{21}$, pod warunkiem, iż cechuje ją rzeczowość, rzetelność oraz adekwatność do konkretnych okoliczności faktycznych ${ }^{22}$. Pracownik może otwarcie, krytycznie, ale - co ważne - we właściwej formie i odpowiednich granicach, wypowiadać się w sprawach dotyczących pracodawcy, przede wszystkim w zakresie organizacji pracy, zwłaszcza jeżeli jego postawę cechuje sumienność, staranność i tego samego wymaga on od innych ${ }^{23}$. W innym wyroku Sąd Najwyższy wskazuje, iż pracownik ma nie tyle prawo, co obowiązek przeciwstawiać się złu, które istnieje na terenie zakładu pracy ${ }^{24}$. Natomiast nawet w takich okolicznościach niedopuszczalne jest, by wyraz jego niezadowolenia przybrał postać odmowy wykonywania poleceń wydawanych przez pracodawcę, a w konsekwencji generował z nim konflikt ${ }^{25}$. W uzasadnieniu do przytoczonego wyroku Sąd Najwyższy wskazał, iż nie należy do pracownika decydowanie o racjonalności działań, których podjęcie poleca mu pracodawca, a on sam powinien powstrzymać się od zachowań, które mogą utrudniać współpracę w ramach zespołu pracowniczego. $\mathrm{W}$ przeciwnym razie wyrażana $\mathrm{w}$ obecności innych pracowników, w obraźliwych słowach, dezaprobata decyzji pracodawcy usprawiedliwi utratę zaufania do pracownika i będzie wystarczającą podstawą wypowiedzenia mu umowy o pracę ${ }^{26}$.

Dopuszczalną krytykę musi cechować również dobra wiara wyrażająca się w subiektywnym przekonaniu, że wypowiadane twierdzenia mają poparcie w faktach, a nie jedynie w plotkach czy informacjach niemających oparcia w rzeczywistości ${ }^{27}$. Oznacza to, że od pracownika wymaga się w takich okolicznościach przede wszystkim staranności i rzetelności przy ocenie prawdziwości przytaczanych informacji, których nie należy utożsamiać ze starannością profe-

20 Wyrok Sądu Najwyższego z dnia 7 grudnia 2006 roku, I PK 123/06. OSNP 2008, nr 1-2, poz. 14 .

${ }^{21}$ Wyrok Sądu Najwyższego z dnia 9 lutego 2006 roku, II PK 160/05, OSNP 2007, nr 1-2, poz. 4.

22 Wyrok Sądu Najwyższego z dnia 25 listopada 2014 roku, I PK 98/14, Legalis nr 1187080.

23 Wyrok Sądu Najwyższego z dnia 7 września 2000 roku, I PKN 11/00, OSNAPiUS 2002, nr 6, poz. 139.

24 Tak: wyrok Sądu Najwyższego z dnia 29 stycznia 1975 roku, III PRN 69/74, OSNCP 1975, nr 7-8, poz. 124.

25 Szerzej: wyrok Sądu Najwyższego z dnia 19 marca 2014 roku, I PK 187/13, Lex nr 1475152.

26 Szerzej: wyrok Sądu Najwyższego z dnia 23 września 2004 roku, I Pk 487/03, Pr. Pracy 2005, nr 5 .

27 Szerzej: wyrok Sądu Najwyższego z dnia 30 września 1960 roku, I CR 634/59, OSNPG 1961, nr 4, poz. 18. 
sjonalną, wymaganą chociażby od dziennikarzy ${ }^{28}$. Warto zaznaczyć, że jedną ze szczególnych odmian publicznej i dozwolonej krytyki pracodawcy będzie prawo do whistleblowingu. Zadaniem whistleblowera, inaczej zwanego sygnalizatorem lub demaskatorem, jest przekazywanie opinii publicznej wiadomości o naruszeniu przepisów i innych nieprawidłowościach mających miejsce w zatrudniającym go zakładzie pracy. Specyfika opisywanych działań musi bezwzględnie opierać się na dobrej wierze kierującej działaniami demaskatora. Wówczas zgłasza on osobom odpowiedzialnym za sprawy etyczne i dyscyplinarne w danym zakładzie pracy przypadki braku uczciwości, rzetelności lub łamania zasad etycznych albo prawa przez innych pracowników czy pracodawcę ${ }^{29}$. Aktualnie w polskim prawie pracy whistleblowing stanowi jedynie zjawisko będące przedmiotem zainteresowania teoretycznego, które wskazuje się - chociaż relatywnie rzadko - jako przykład szczególnej odmiany dozwolonej krytyki pochodzącej od pracownika.

W prowadzonych rozważaniach należy zasygnalizować, że obiektywnie uzasadniona krytyka skierowana pod adresem pracodawcy musi posiadać odpowiednią formę. Nawet dozwolona krytyka, lecz wyrażona w nieodpowiedniej formie bądź skierowana do przypadkowego grona odbiorców, może skutkować powstaniem realnej szkody nie tylko lub niekoniecznie po stronie pracodawcy, ale także rozszerzać się na pozostałych współpracowników i ich potencjalnych klientów. W jednym z wyroków Sąd Najwyższy wskazał, że upublicznienie zarzutów skierowanych pod adresem pracodawcy, potwierdzonych jedynie częściowo, może stanowić podstawę do wypowiedzenia pracownikowi umowy o pracę z powodu utraty zaufania i tym samym braku możliwości kontynuacji dalszej współpracy. W przedmiotowym wyroku przyjęto, że upublicznianie określonych zarzutów pod adresem pracodawcy nie zawsze należy utożsamiać z ciężkim naruszeniem podstawowych obowiązków pracowniczych ${ }^{30}$, szczególnie gdy nie można przypisać znacznego nasilenia złej woli oraz świadomego działania zmierzającego do zagrożenia interesów pracodawcy ${ }^{31}$. W takim układzie mamy jednak do czynienia z brakiem należytego uwzględnienia roli aspektu komunikacyjnego współczesnych struktur społecznych. Niewątpliwie przykładem takich działań będzie umieszczanie niepochlebnych wypowiedzi w przestrzeni wirtualnej, co z uwagi na powszechność Internetu staje się zjawiskiem częstym. Internet może stać się narzędziem zarówno komunikacji masowej, jak i interpersonalnej, o czym za-

28 Szerzej: Sąd Najwyższy w uzasadnieniu wyroku z dnia 28 sierpnia 2013 roku, I PK 48/13, Legalis nr 830616.

29 W. Rogowski, Ochrona sygnalistów (ang. whistleblower) jako przejaw społecznej odpowiedzialności biznesu, www.cars.wz.uw.edu.pl/tresc/konferencje/11/Rogowskireferat.pdf [data dostępu: 10.05.2015].

30 Szerzej: wyrok Sądu Najwyższego z dnia 18 lipca 2012 roku, I PK 44/12, Lex nr 1228441.

31 Szerzej: wyrok Sądu Najwyższego z dnia 16 listopada 2006 roku, II PK 76/06, OSNP 2007, nr 21-22, poz. 312. 
sadniczo decyduje osoba $\mathrm{z}$ niego korzystająca ${ }^{32}$. W sieci tworzone są strony internetowe ukierunkowane na wymianę niepochlebnych wypowiedzi czy wręcz rozległych dyskusji związanych z pracodawcami zatrudniającymi pracowników, z uwzględnieniem poszczególnych regionów kraju. W takim przypadku istnieje nie tylko poważne prawdopodobieństwo przekroczenia granic dozwolonej krytyki, ale dodatkowo niepochlebne opinie trafiają poza krąg osób związanych z danym pracodawcą i jego pracownikami. Krytyka powstała we wskazanych okolicznościach będzie zatem podyktowana subiektywnymi względami pracownika, zaś jej przekaz jest świadomie nakierowany na obraźliwą formę mającą postać napaści osobistej ${ }^{33}$.

Innym, równie częstym, przykładem opisywanych działań są słowne krytyczne i nieuzasadnione uwagi dotyczące strategii rozwoju czy kierowania firmą, wypowiadane przez pracownika w szerszym gronie odbiorców, niekoniecznie będących jej pracownikami, a jedynie osobami związanymi z analogiczną bądź pokrewną branżą. Opisana grupa zachowań stanowi zatem potencjalne zagrożenie wobec sytuacji finansowej zakładu pracy, ale także może bezpośrednio wpływać na stabilizację zatrudnienia względem pozostałych pracowników. W konsekwencji mogą one powodować realne naruszenie zasad współżycia społecznego przez odczucie atmosfery napięcia, konfliktu i poczucia zagrożenia spokoju, bez względu na intencje, które nakłoniły do ich tworzenia danego pracownika ${ }^{34}$. Natomiast po stronie pracodawcy lub osób działających w jego imieniu krytyczne oceny mogą skutkować naruszeniem dóbr osobistych. W orzecznictwie sądowym podkreśla się, że do naruszenia dóbr osobistych w wyniku wypowiedzi wartościującej określonego kręgu osób może dojść wyjątkowo i tylko wówczas, gdy wypowiadane treści ocenne nie znajdują oparcia w prawdziwym, ocenianym zdarzeniu ${ }^{35}$.

Niezależnie od powyższego podkreślenia wymaga, iż w każdym przypadku ocena prawnopracowniczej odpowiedzialności z tytułu przekroczenia granic dozwolonej krytyki pracodawcy powinna uwzględniać zasady ochrony dóbr osobistych wynikających z kodeksu cywilnego, jak również odpowiedzialności prawnokarnej, co z uwagi na ściśle ograniczony aspekt prowadzonych rozważań zostanie świadomie pominięte.

Nieuzasadniona krytyka jest zjawiskiem, które odczuwa także pracownik. Każdorazowo przeczy ona przyzwoitej realizacji jednego z podstawowych obo-

32 Szerzej: S. Kowalski, Zniesławienie w Internecie, „Służba Pracownicza” 2014, nr 3, s. $10-11$.

33 Szerzej: wyrok Sądu Najwyższego z dnia 11 grudnia 1952 roku, C 2556/52, PiP 1953, nr 7 , s. 128.

34 Szerzej: wyrok Sądu Najwyższego z dnia 21 lutego 1997 roku, I PKN 15/97, OSNAPiUS 1997, nr 20, poz. 400.

35 Zob. m.in. wyrok Sądu Apelacyjnego w Krakowie z dnia 2 marca 1994 roku, I ACr 76/94, PS 2000, nr 3, s. 117; wyrok Sądu Najwyższego z dnia 10 listopada 2005 roku, V CK 314/05. 
wiązków spoczywających na pracodawcy, tj. zatrudnienia w środowisku pracy zgodnie z poszanowaniem zasad współżycia społecznego. Należy zaznaczyć, że autorem nieuzasadnionej krytyki może być nie tylko pracodawca, ale i współpracownicy. Jednakże to na pracodawcy spoczywa obowiązek kierowania zakładem pracy w taki sposób, by wskazane zjawisko eliminować. Zdaniem Sądu Najwyższego w takim przypadku pracodawca jest zobowiązany do podjęcia wszelkich działań, które niepożądanym zjawiskom w pracy położą kres, nie wykluczając niezwłocznego rozwiązania umowy o pracę z pracownikiem zakłócającym jej prawidłowy proces ${ }^{36}$. Nieuzasadniona krytyka pracownika zawsze narusza jego godność, i to zarówno tę w ujęciu najszerszym, jak i osobowościową, powstałą na kanwie pracowniczego zatrudnienia. W konsekwencji może ona bowiem spowodować utratę zaufania niezbędnego przy wykonywaniu zawodu bądź innej prowadzonej przez niego działalności ${ }^{37}$. Istotne jest, by ocena, czy rzeczywiście doszło do naruszenia lub zagrożenia dobra osobistego konkretnego człowieka, była przeprowadzona według obiektywnych kryteriów. Wówczas w pierwszej kolejności należy brać pod uwagę reakcję opinii publicznej na konkretne zdarzenie, a nie subiektywne odczucie osoby, której dotyczy, gdyż z założenia wystąpienie sytuacji konfliktowej z jej udziałem wyklucza istnienie obiektywizmu ${ }^{38}$. W takim przypadku należy również wziąć pod uwagę okoliczności, które wyłączają lub zmniejszają bezprawność określonych działań pracodawcy. Do takich okoliczności, zgodnie z utrwalonym orzecznictwem sądowym, można zaliczyć wykonywanie prawa podmiotowego, ochronę interesu nadrzędnego czy zgodę wyrażoną przez samego uprawnionego ${ }^{39}$. Natomiast w przypadku, gdy nieuzasadniona krytyka pochodzi bezpośrednio od pracodawcy, każdorazowo stanowi ona zaprzeczenie zasad współżycia społecznego, niezbędnych w środowisku pracy. Zdaniem Sądu Najwyższego istnieje też możliwość przypisania mu deliktu stanowiącego czyn niedozwolony podlegający reżimowi odpowiedzialności cywilnoprawnej na podstawie art. 415 kodeksu cywilnego ${ }^{40}$.

Konkludując, nie sposób jednak rozwijać sił wytwórczych, nie rozwijając przy tym zdolności do krytycznego oraz otwartego myślenia. Należy mieć przy tym na uwadze, że wadliwa organizacja instytucji społecznych może negatywnie wpływać na środowisko społeczne człowieka przez tworzenie takich form organizacji więzi międzyludzkich, które wykluczają porozumiewanie się oparte

36 Szerzej: wyrok Sądu Najwyższego z dnia 29 czerwca 2005 roku, I PK 290/04, OSNP 2006, nr 9-10, poz. 149.

37 Wyrok Sądu Najwyższego z dnia 9 września 2002 roku, IV CKN 1402/00.

38 Wyrok Sądu Najwyższego z dnia 10 września 1999 roku, III CKN 938/98, OSNC 2000, nr 3, poz. 56.

39 Szerzej na ten temat: D. Dörre-Kolasa, op. cit., s. 38-39.

40 Szerzej: wyrok Sądu Najwyższego z dnia 11 czerwca 2003 roku, I PK 273/02, OSNP 2004, nr 16, poz. 279. 
na normach etycznych. Dlatego tak istotne jest tworzenie struktur społecznych pozwalających porozumiewać się szczerze i w sposób wolny od obaw ${ }^{41}$.

\section{BIBLIOGRAFIA}

Bosak M., Danilewicz A., Odpowiedzialność cywilna i karna za mobbing, „Prokuratura i Prawo” 2010, $\mathrm{nr} 4$.

Bosak M., Habrat D., Granice krytyki w stosunkach pracy, [w:] 40 lat Kodeksu pracy, pod red. Z. Górala, M.A. Mielczarka, Warszawa 2015.

Ciupa S., Niedozwolona krytyka pracodawcy ze strony pracownika jako przyczyna wypowiedzenia umowy o prace,, „Monitor Pracy” 2002, nr 20.

Dörre-Kolasa D., Komentarz do art. 100, [w:] Kodeks pracy. Komentarz, pod red. A. Sobczyk, Warszawa 2014.

Kowalski S., Zniesławienie w Internecie, „Służba Pracownicza” 2014, nr 3.

Kryszkiewicz M., Godność w prawie pracy, [w:] Wartości i interesy a prawo pracy, pod red. M. Włodarczyka, Łódź 2014.

Mały stownik języka polskiego, pod red. E. Sobol, Warszawa 2004.

Mazurek F.J., Godność osoby ludzkiej podstawa praw człowieka, Lublin 2001.

Morawski L., Gtówne problemy wspótczesnej filozofii prawa. Prawo w toku przemian, Warszawa 2005.

Rogowski W., Ochrona sygnalistów (ang. whistleblower) jako przejaw społecznej odpowiedzialności biznesu, www.cars.wz.uw.edu.pl/tresc/konferencje/11/Rogowskireferat.pdf [data dostępu: 10.05.2015].

Sobczyk A., Prawo pracy w świetle Konstytucji RP, t. 1, Warszawa 2013.

Szewczyk H., Mobbing w stosunkach pracy, Warszawa 2012.

Szewczyk H., Ochrona dóbr osobistych w zatrudnieniu, Warszawa 2007.

Wieloaspektowość mobbingu w stosunkach pracy, pod red. T. Wyki, C. Szmidta, Warszawa 2012.

Włodarczyk M., Wartości i interesy a prawo pracy - tytułem wstępu, [w:] Wartości i interesy a prawo pracy, pod red. M. Włodarczyka, Łódź 2014.

Wyrok Sądu Apelacyjnego w Krakowie z dnia 2 marca 1994 roku, I ACr 76/94, PS 2000, nr 3.

Wyrok Sądu Apelacyjnego w Katowicach z dnia 15 grudnia 2006 roku, III APa170/05, OSA/Kat, 2007, nr 3, poz. 4.

Wyrok Sądu Najwyższego z dnia 11 grudnia 1952 roku, C 2556/52, PiP 1953, nr 7.

Wyrok Sądu Najwyższego z dnia 30 września 1960 roku, I CR 634/59, OSNPG 1961, nr 4, poz. 18. Wyrok Sądu Najwyższego z dnia 29 stycznia 1975 roku, III PRN 69/74, OSNCP 1975, nr 7-8, poz. 124. Wyrok Sądu Najwyższego z dnia 11 kwietnia 1984 roku, I PR 34/84, OSPiKA 1985, nr 9, poz. 161. Wyrok Sądu Najwyższego z dnia 21 lutego 1997 roku, I PKN 15/97, OSNAPiUS 1997, nr 20, poz. 400.

Wyrok Sądu Najwyższego z dnia 7 marca 1997 roku, I PKN 28/97, OSNAPiUS 1997, nr 24, poz. 487.

Wyrok Sądu Wyrok Sądu Najwyższego z dnia 11 czerwca 1997 roku, I PKN 202/97, OSNAPiUS 1998, nr 10, poz. 297.

Wyrok Sądu Najwyższego z dnia 1 października 1997 roku, I PKN237/97, OSNAPiUS 1998, nr 14, poz. 420.

Wyrok Sądu Najwyższego z dnia 10 września 1999 roku, III CKN 938/98, OSNC 2000, nr 3, poz. 56.

Wyrok Sądu Najwyższego z dnia 13 października 1999 roku, I PKN 296/99, OSNAPiUS 2001, nr 4, poz. 114.

${ }^{41}$ L. Morawski, op. cit., s. 159-160. 
Wyrok Sądu Najwyższego z dnia 7 września 2000 roku, I PKN 11/00, OSNAPiUS 2002, nr 6, poz. 139.

Wyrok Sądu Najwyższego z dnia 9 września 2002 roku, IV CKN 1402/00.

Wyrok Sądu Najwyższego z dnia 11 czerwca 2003 roku, I PK 273/02, OSNP 2004, nr 16, poz. 279.

Wyrok Sądu Najwyższego z dnia 23 września 2004 roku, I Pk 487/03, Pr. Pracy 2005, nr 5.

Wyrok Sądu Najwyższego z dnia 12 stycznia 2005 roku, I PK 145/04, OSNP 2005, nr 16, poz. 243.

Wyrok Sądu Najwyższego z dnia 29 czerwca 2005 roku, I PK 290/04, OSNP 2006, nr 9-10, poz. 149.

Wyrok Sądu Najwyższego z dnia 10 listopada 2005 roku, V CK 314/05.

Wyrok Sądu Najwyższego z dnia 9 lutego 2006 roku, II PK 160/05, OSNP 2007, nr 1-2, poz. 4.

Wyrok Sądu Najwyższego z dnia 16 listopada 2006 roku, II PK 76/06, OSNP 2007, nr 21-22, poz. 312.

Wyrok Sądu Najwyższego z dnia 7 grudnia 2006 roku, I PK 123/06. OSNP 2008, nr 1-2, poz. 14.

Wyrok Sądu Najwyższego z dnia 2 lutego 2011 roku, II PK 189/10, MoPr 2011, nr 8.

Wyrok Sądu Najwyższego z dnia 18 lipca 2012 roku, I PK 44/12, Lex nr 1228441.

Wyrok Sądu Najwyższego z dnia 28 sierpnia 2013 roku, I PK 48/13, Legalis nr 830616.

Wyrok Sądu Najwyższego z dnia 19 marca 2014 roku, I PK 187/13, Lex nr 1475152.

Wyrok Sądu Najwyższego z dnia 25 listopada 2014 roku, I PK 98/14, Legalis nr 1187080.

\section{SUMMARY}

The article is devoted to the phenomenon of criticism in labour relations, which, due to contractual, subordinated and continuous nature of employment, feels both the employee and the employer. Distinction of the justified and unjustified criticism was made in the content, together with reference to the latest judicature of the Supreme Court. In the end it was emphasized, that obligation to care about working environment free from any undue criticism reflects to stabilize employment and largely determines both the course of teamwork, which means that it becomes general duty, rather than private of individual person.

Keywords: phenomenon of criticism; justified criticism; unjustified criticism; employment relationship; employee; employer 